\title{
Raising awareness about gender and ethnic inequality through infographics and critical literacy: a teaching-learning narrative with high school students at a Federal Institute.
}

Roberta Barros da Fonseca ${ }^{1}$

\begin{abstract}
This teaching narrative aims at sharing activities involving the use of infographics during the English classes for computer programming sophomore year at the Federal Institute of São Paulo (IFSP), raising students' awareness through critical literacy and statistics analysis. The activities reported here are based on Luke's remarks (2014) about power struggles, control of information and interpretation of text and discourse, understanding the term critical literacy as the possibility to use print technologies and other media of communication to analyze, critique and transform systems governing the social field.
\end{abstract}

Keywords: English language teaching. Technical high school. Critical Literacy.

\section{Resumo}

Essa narrativa de ensino tem como principal objetivo compartilhar atividades envolvendo o uso de infográficos durante as aulas de inglês do segundo ano de informática do ensino médio integrado do Instituto Federal de São Paulo (IFSP), aumentando a conscientização dos alunos através do letramento crítico e análise de estatísticas. As atividades aqui relatadas são baseadas nas considerações de Luke (2014) sobre os conflitos de poder, controle de informação e interpretação do texto e do discurso, compreendendo o termo letramento crítico como o uso de tecnologias impressas e outras mídias de comunicação para analisar, criticar e transformar os sistemas que governam o campo social.

Palavras-chave: Ensino da língua inglesa. Ensino médio técnico. Letramento crítico.

\section{Introduction}

Regarding the context of language teaching and activities to use in the classroom, there is a lot of ground to cover, analyzing ideologies, cultural flow and situated practices in order to better reflect about the use of technology, diverse language practices and social structures in the community where learning takes place. The socio-historical context allows us to rethink the teaching learning process, bringing up relevant issues for reading, interpretation and discussion in the classroom. According to Luke (2014, p. 20) "new media are transforming relations of production and consumption" globally as well as locally and our students should be engaged in this complex movement, understanding "how and where texts are used, by whom and in whose interests".

\footnotetext{
${ }^{1}$ Mestre em Linguística Aplicada pela UFRJ. Professora de Inglês no IFSP/ GPLLE.
} 


\section{LÍNGUATEC}

Considering the critical literacy approach (LUKE, 2014) and MEC guidelines to tackle important issues such as ethnic diversity, the classroom activities reported here were designed for a sophomore class in a computer programming course, using Gemaa ${ }^{2}$ infographics and United Nations campaign Balance for Betteß ${ }^{3}$ as a starting point.

The term critical literacy, part of Multiliteracies Pedagogy, tries to "answer the demands of contemporary society, formed in/ by the tension between global forces and local movements and strongly characterized by inequality of different sources" (ROCHA et al.,2016, p. 42)4. Luke (2014, p. 21) points out that critical literacy represents a "political orientation", analyzing, criticizing and transforming texts and social, cultural, political contexts through language use and world problems awareness. The critical literacy perspective invites us, then, for questioning how the discourse, socially and politically constructed, influences and transforms the reality and local surroundings.

Monte Mór (2015, p. 42) also shows that "critical literacy comes from the premise that language has a political nature due to power relations" which take place during its use and it is also surrounded by ideologies in its different contexts. These definitions regarding the term critical literacy bring up important questions as far as teaching and learning English go: how can language, different texts, discourse and information make a difference in the classroom and in the world? From what devices and sources are we encouraging interpretations and discussions in the classroom? How can critical literacy, developed in the classroom, be evolved to a social action path, encouraging transforming agendas, active engagement and agency and not simply awareness?

\section{Theoretical guidelines and classroom Reading activities}

This teaching narrative related to critical literacy can be described as a pedagogical proposal that reviews and reflects language, communication, culture, diversity, power, meaning making, participation forms, agency and citizenship (MONTE MÓR, 2015), engaging students in analyzing and interpreting texts and data about gender and ethnic inequality in Brazil. Tílio (2015, p. 51) shows that a critical literacy proposal allows learners to be critical

\footnotetext{
${ }^{2}$ Available at http://gemaa.iesp.uerj.br/category/infografico/

${ }_{3}^{3}$ Available at https://www.internationalwomensday.com/Theme

4 Translation from Portuguese by the author
} 


\section{LÍNGUATEC}

citizens, being "empowered to use the language in a critical and responsible way, aware of their role in a globalized world and prepared to act in it". The author suggests the use of material connected to learners' social challenges and environment, tackling cross-cutting themes that help raise awareness about cultural, social and political differences. In MEC High School Guidelines (BRASIL, 2006), we also find themes such as diversity, rights, social justice, values, conflicts, differences among other topics, proposing a critical reading of the world and the learners' own reality. The author also points out that critical literacy "does not ignore other work with linguistic and lexical skills, for example, but expands it to interpretation and social transposition in order to make the learning experience a social practice" (TÍLIO, 2015, p.63).

In other words, Tílio (2015) shows that the focus on cross-cutting themes such as work, citizenship, social justice, gender equality and others are part of our social contemporary life and using language to read and reflect on these issues can help learners construct themselves and their social surroundings as well. Consequently, teaching English can also serve as "a space to show learners how cross-cutting themes are tackled in the foreign language and, from there, propose critical reflections and transpositions to learner's social spaces" (TÍLIO, 2015, p.57). According to the author, critical literacy helps us understand language teaching and learning as a process, making it possible for learners to construct meanings based on different sources and social contexts where language is present in everyday life all over the globe, keeping in mind the critical perspective and bridging gaps between the global and the local aspects. Rocha e Maciel (2016) also call attention to the possibility that critical (re)appropriation of language and actions can encourage experiences that recreate learners' social reality. The authors say that language teaching for democratic awareness is focused on discourse and for this reason should also be critical and transgressive, being aware of power relations, identity and representations in society and language policies.

Now, considering MEC High School guidelines and the critical literacy proposal, how can English teachers alert learners about the process of meaning making based on different social and political contexts in a contemporary world that is constantly changing? How can critical literacy tune learners to questioning and reframing ideological and power relations that have been considered natural by some people? How can critical reflections and global problems be developed and transported to learners' local settings? How can concrete and hands-on activities be created in order to engage learners in language practice, considering 


\section{LÍNGUATEC}

the complex relations in society and discourse? These questions helped frame the reading activities for the sophomore year classes reported here, suggesting cross-cutting themes towards certain issues.

It all started when students got warmed up on the occasion of International Women's Day, reading the resources provided by the United Nations for classroom engagement and discussion about gender and opportunities. These activities were called Balance for Better 5 . Besides reading the fact check sheet about the date and its history, learners started reading about the six women role models from different countries and cultural backgrounds in order to come up with their own contribution afterwards. They prepared a wall in the school hallway, sharing these role model stories and voices, fighting for equal rights as far as gender goes. Besides expanding vocabulary, they came up with important questions to tackle in the community as well, considering the differences in sports, for example. They decided to present their contribution, adding the Brazilian soccer player Marta to the United Nations list for role models in Balance for Bette ${ }^{6}$ campaign. The exhibit was shared in the hallway for other high school classes and under-graduate students to see, bringing up an important theme for discussion and agency.

This reading activity and exhibit sharing women's accomplishments and struggles motivated the class to further discussion regarding representation, including gender as well as ethnic differences in Brazilian newspapers and judiciary. Students were exposed to infographics published by Gemaa7, a UERJ research group that focuses on affirmative actions and learners started analyzing the quantitative data. First of all, they were asked to analyze the language presented in the infographics and see if any important information should be included along with the statistics. Then, they came up with an important observation, saying that only one infographic presented the proportion compared to the country overall population statistics, making it more effective to expose the huge gap in terms of gender and ethnic differences countrywide. Students were impressed by the small percentage of representation regarding gender and race, questioning how values, interests and standpoints have been shared in Brazilian newspapers considering men and women population in the

\footnotetext{
5 Available at https://www.internationalwomensday.com/Activity/12216/TeachStarter

${ }^{6}$ Available at https://www.internationalwomensday.com/Activity/12216/TeachStarter

7 Available at http://gemaa.iesp.uerj.br/infografico/brazilian-newspapers-gende-and-race-of-opinioncolumnists-in-the-main-newspapers/
} 
country and especially how voices need to be spread and heard. After all, they questioned from what point of view and perspective we have been exposed to the country's problems.

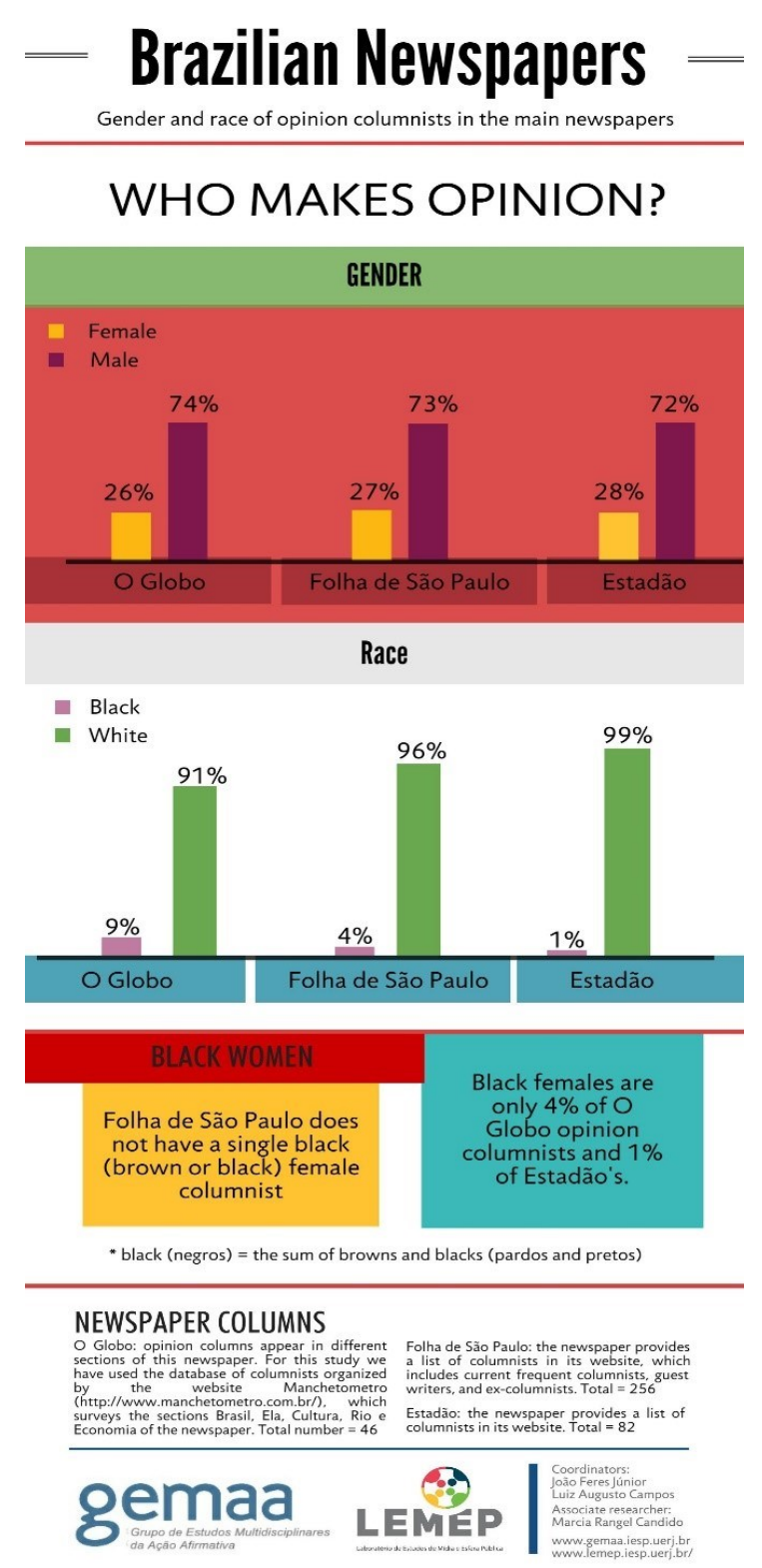

Figure 1. Who makes opinion?

Source: Gemaa/IESP/UERGS, [2019?].

They also pointed out that such information does not seem to be shared in order to fight for more equality and representation in nationwide and local papers. Recognizing how texts are historically marginalized and excluded can be a first step, but more equitable representation needs to be achieved and conquered. The other two groups of students focused on gender and race in Brazilian judiciary and they were also surprised by the data presented by Gemaa research group. 


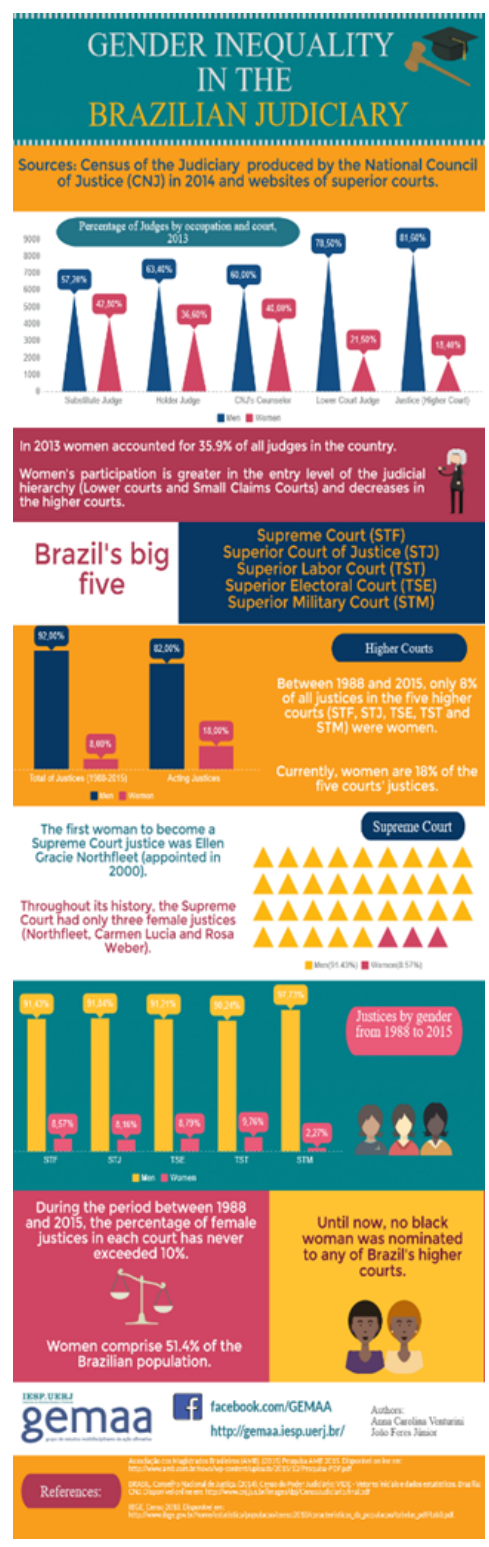

Figure 2. Gender in Brazilian judiciary

Source: Gemaa/IESP/UERGS, [2019?]. 

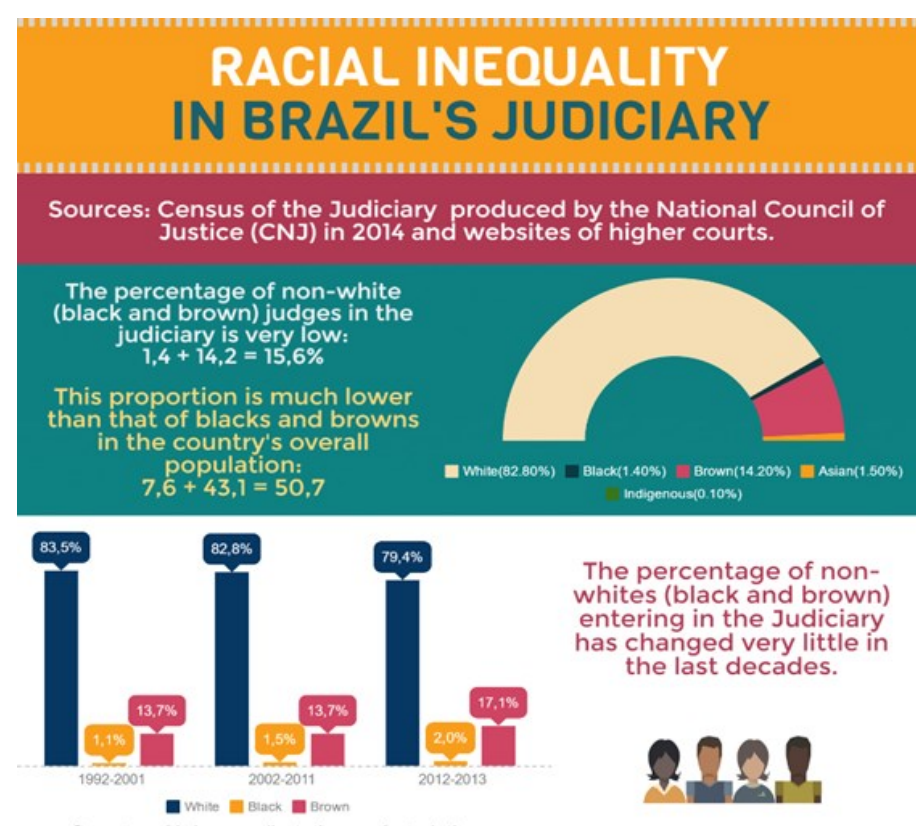

Percentage of Judges according to the year of entry in the carees

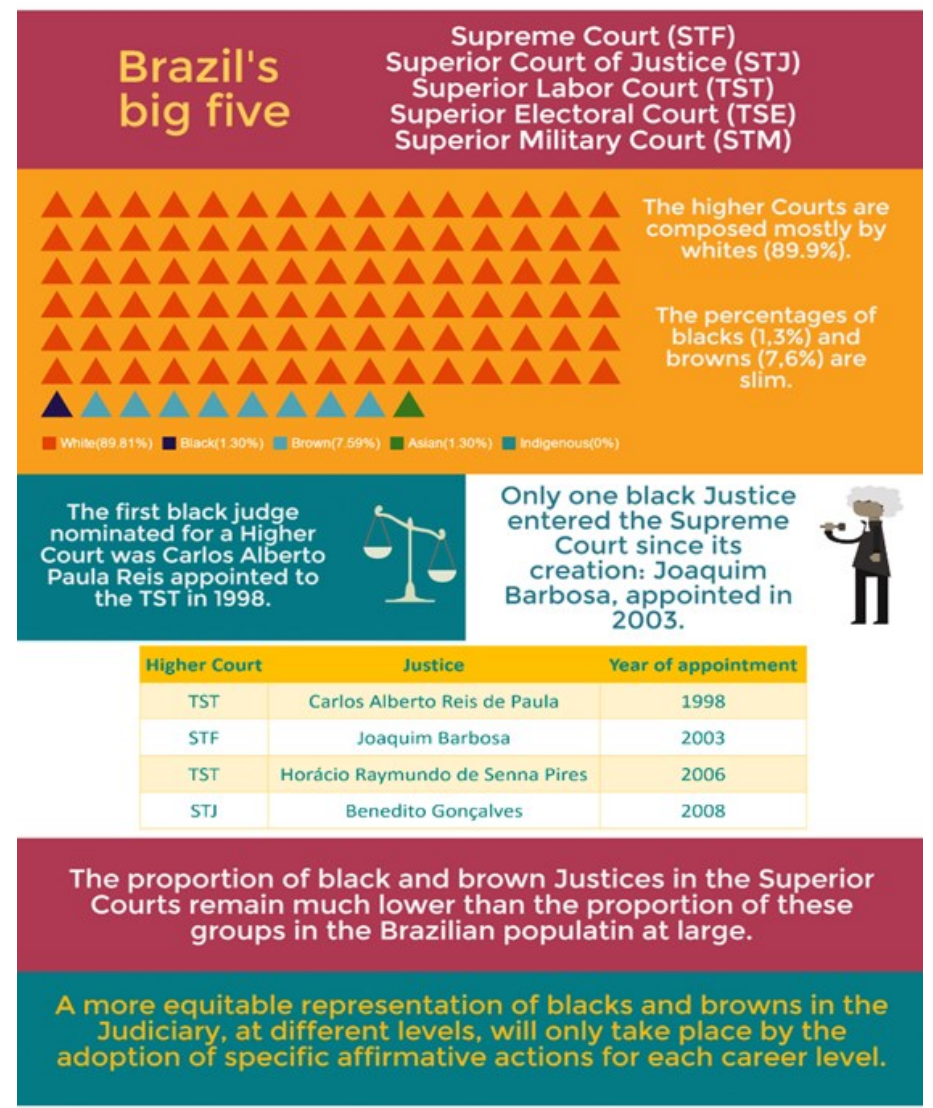

\section{gemaa}

f facebook.com/GEMAA

http://gemaa.iesp.uerj.br/

Authors:
Anna Carolina Venturin
Joảo Feres Junior

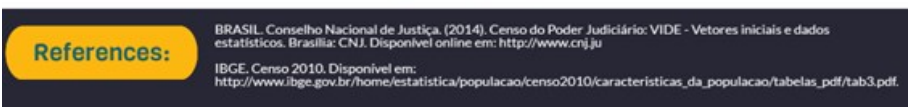

Figure 3. Race in Brazilian judiciary Source: Gemaa/IESP/UERGS, [2019?]. 
After all the reading and critical analysis, the students were encouraged to look for a tool to create their own infographic afterwards and come up with frames that would be relevant to school campus and community in general. That is how they got familiar with Piktochart ${ }^{8}$, "an intuitive tool that helps people tell stories with the visual impact they deserve, using infographic patterns to share data and not only spreadsheets". The groups started browsing Piktochart in English to create and design a pattern for a future infographic that would bring information about gender and ethnic differences on campus among faculty members, students and technical positions. However, they decided not to follow Gemaa design and categories, saying that some people on campus do not describe themselves as women or men and an LGBT section should be considered in order to show representation. One group gave the example of the newspaper opinion section presented by Gemaa group, saying that we do not know from that perspective how gays have space to share their voices on newspapers in the country since the section was only divided by men and women. So, after the United Nations reading and the infographics analysis, the students have been reflecting on local data as far as gender and ethnic differences go in order to design their own infographic as a final term assignment afterwards, framing the reality on campus.

\section{Final remarks}

As Luke (2014) points out, critical literacy has been the object of a few decades discussion in education settings, including in Brazil with Paulo Freire educational projects as a starting point. Since then, "approaches to critical literacy have been developed through feminist, postcolonial, poststructuralist and critical race theory, critical linguistics and cultural studies" (LUKE, 2014, p. 21). The author, then, defines the work with critical literacy as a "political orientation to teaching and learning and to the cultural, ideological and sociolinguistic content of the curriculum, which is focused on the uses of literacy for social justice in marginalized and disenfranchised communities" (LUKE, 2014, p.21). In other words, the author shows that cognitive models of reading and writing should include "cultural knowledges and texts of historically marginalized and excluded communities" as well as "interests, values and standpoints of one's communities and cultures", criticizing and transforming dominant ideologies, cultures and institutions.

\footnotetext{
${ }^{8}$ Available at https://piktochart.com/
} 


\section{LIINGUATEC}

With all this in mind, it is crucial to understand that a key element to critical literacy is to frame cultural and political analysis of texts, constructing and reconstructing social relations. It cannot only be about identifying author bias in the texts as some traditional approaches have done, it should be about encouraging the agency and power of readers and writers, getting learners' voices and contributions closer to the curriculum. This way, learners can "question class, race and gender relations through dialogic exchange" (LUKE, 2014, p 25). Along with lexico-grammatical structure of the language, social, political and cultural aspects can also be tackled in order to understand how language in use is presented to represent and shape the sociopolitical world. "As a cultural and linguistic practice, then, critical literacy entails an understanding of how texts and discourses can be manipulated to represent, and indeed, alter the world" (LUKE, 2014, p.28). Monte Mór (2015) goes a step further and suggests individual, community and global perspectives to work with the critical literacy approach, asking learners what they think about the topic discussed, finding out what other people in the community think about the same issue and, finally, figuring out what other countries or regions of the same country think about the discussion.

Considering the practical aspect, then, Jordão (2017, p. 205) argues that critical literacy "allows that each local space determines its procedures, methodology and literacy practices

- there is no specific method, a determined script or a set of procedures recommended by critical literacy: this world vision is based on local knowledge respect", being part of the post method perspective. Consequently, in the critical literacy approach in language teaching and learning, language represents a social practice (ROCHA et al, 2014) and learners bring their values, knowledge, social and critical perspective to the classroom, working with others in a collaborative way in order to (re)construct meanings through language use. Such perspective can allow more space for different voices in the classroom, inviting all to the discussion and interpretation of meaning in order to seek for social justice in marginalized communities and, later on, work on social actions together.

\section{References}

BRASIL. Orientações curriculares para o ensino médio: Linguagens, códigos e suas tecnologias / Secretaria de Educação Básica. Brasília: MEC/SEMTEC, 2006.

JORDÃO, C.M. Birds of different feathers: algumas diferenças entre letramento crítico, 
pedagogia crítica e abordagem comunicativa. In: TAKAKI, N. H.; MACIEL, R. F. (Orgs.). Letramentos em terra de Paulo Freire. 2. ed. São Paulo: Pontes Editores, 2015. p. 195-207. LUKE, A. Defining critical literacy. In: PANDYA, J. Z.; ÀVILA, J. (Eds.). Moving critical literacies forward: a new look at praxis across contexts. New York: Routledge, 2014. p. 19-31.

MONTE MÓR, W. Crítica e Letramentos Críticos: reflexões preliminares. In: ROCHA, C. H.; FRANCO MACIEL, R. (Orgs.). Língua Estrangeira e Formação Cidadã: por entre discursos e práticas. Coleção: Novas perspectivas em Linguística Aplicada. v. 33, Campinas, SP: Pontes Editores, 2013.

. Letramentos críticos e expansão de perspectivas: diálogo sobre práticas. In: JORDÃO.; MARTINEZ, J.; MONTE-MÓR, W. (Orgs.). Letramentos em prática na formação inicial de professores de inglês. Campinas: Pontes, 2018.

ROCHA, C. H. et al. Entre o ontem e o amanhã: narrativas e propostas sobre educação crítica em língua estrangeira e tecnologias em contexto universitário. Raído, v. 10, p. 40-59, 2016. TílIO, R. Repensando a abordagem comunicativa: multiletramentos em uma abordagem consciente e conscientizadora. In: ROCHA, C. H.; FRANCO MACIEL, R. (Orgs.). Língua Estrangeira e Formação Cidadã: por entre discursos e práticas. Coleção: Novas perspectivas em Linguística Aplicada. v. 33, Campinas, SP: Pontes Editores.

Data de submissão: 03/09/2019. Data de aprovação: 15/10/2019. 